\title{
Deliberation, unjust exclusion, and the rhetorical turn
}

\author{
Steven Gormley \\ Philosophy Department, University of Essex, Wivenhoe Park, CO4 3SQ, UK \\ segorm@essex.ac.uk
}

\begin{abstract}
Theories of deliberative democracy have faced the charge of leading to the unjust exclusion of voices from public deliberation. The recent rhetorical turn in deliberative theory aims to respond to this charge. I distinguish between two variants of this response: the supplementing approach and the systemic approach. On the supplementing approach, rhetorical modes of political speech may legitimately supplement the deliberative process, for the sake of those excluded from the latter. On the systemic approach, rhetorical modes of political speech are legitimate within public deliberation, just so long as they result in net benefits to the deliberative system. I argue that neither of these two approaches adequately meets the unjust exclusion charge. Whereas the supplementing approach does not go far enough to incorporate rhetorical speech into public deliberation, the systemic approach goes too far by legitimizing forms of rhetoric that risk only exacerbating the problem of unjust exclusion. More constructively, I draw on Aristotle's conception of rhetoric, as an art (technē) that is a counterpart to dialectic, to argue for a constitutive approach to rhetoric. I show how this approach provides a more expansive notion of deliberation that remains normatively orientated.
\end{abstract}

Keywords: Aristotle; deliberative democracy; deliberative system; exclusion; manipulation; rhetoric

The task of deliberative democratic theory is to give an account of inclusive processes of deliberation. The aim is to achieve democratic legitimacy and to secure equality, by creating and nourishing the conditions of mutual respect between differently situated social actors. Critics, however, have argued that traditional approaches to this task rely on a restrictive conception of rational argumentation and that this unjustly excludes certain voices from public deliberation. In response to this Unjust Exclusion Charge (hereafter UEC), deliberative theory has recently taken a rhetorical turn. While it has brought with it a more sophisticated account of deliberation, I shall argue that, in the ways the rhetorical turn has so far been implemented, this approach remains inadequate to answer the UEC. However, I shall further argue that Aristotle's account of rhetoric can help us to hold on to the advances made through the rhetorical turn, while avoiding the sources of its failure as a response to the UEC.

I shall begin by providing a brief sketch of the UEC. I shall then introduce one form the rhetorical turn has taken in deliberative theory: the supplementing approach. I shall argue that, although this approach offers a more expansive notion of deliberation, it does not go far enough to answer the UEC. However, I shall further consider an alternative form that the rhetorical turn has more recently taken: the systemic approach. This approach promises a better response to the UEC by appealing to systemic standards of evaluation. While the systemic approach expands significantly the forms of communication that are admitted into public deliberation, we shall see that it does so at the cost of sacrificing core deliberative ideals in specific instances, the likely result of which is the exclusion of those struggling to gain deliberative standing. Finally, I shall show how Aristotle's constitutive approach, in 
which rhetoric is understood as an art (techne $)$ that is a counterpart to dialectic, furnishes resources to develop an account that provides for the more inclusive notion of deliberation that both the supplementing and systemic approaches seek, while addressing the worries that motivate each.

\section{The Unjust Exclusion Charge}

While acknowledging cultural pluralism, and the fact that differently situated social actors may compromise and agree for different reasons, Jürgen Habermas insists that 'the consensus brought about through argument must rest on identical reasons that are able to convince the parties in the same way' (1997, p. 344). Orientated toward such a rational consensus, participants must 'look beyond what is good for them and examine what lies equally in the interest of all' (1997, p. 102). This requires an 'impartial evaluation of action conflicts' (1997, p. 97). Thus, rational consensus is seen as providing a procedural answer to the problem of pluralism. The strategy is to anchor the validity of any particular norm to the outcome of a rational deliberation that would be open to all affected, where each participant adopts an impartial perspective and puts forward claims equally in the interest of all. The aim is thereby to reach a rational consensus in which differently situated actors arrive at collective decisions that are seen by all participants as legitimate. In this process, 'only...the compelling force of the better argument' would move participants (1997, p. 10). The reasons offered in such a process would thus be empowered with a consensus-producing force.

Critics, however, have argued that this approach models deliberation on a restrictive account of rational argumentation that leaves certain voices unjustly excluded from public deliberation. Although deliberative theory sets out formal procedures that guarantee all those affected by a norm a place at the deliberative table, critics claim that privileging certain modes of speech denies certain participants an effective voice in deliberation. Included formally, they are excluded actually (Sanders, 1997; Young, 2001).

On this account, deliberativists fail to appreciate what Tully calls '[d]ifferent practices of reasoning-with-others'. Grounded in culturally distinctive repertoires of practical skills, know-how, and ways of relating to one another, Tully argues that 'culturally diverse practices of deliberation' are not something from which we can unproblematically abstract away (2002, p. 223). Young makes a related point when she argues that 'the norms of deliberation are culturally specific' and that, by failing to acknowledge this, proponents of deliberative democracy are in fact defending views that serve to devalue and unjustly silence alternative forms of speech (1996, p. 123).

To find oneself excluded by the dominant model of deliberation is therefore to confront a choice: either to return the ticket and refuse to play the game, in which case one is left excluded on the margins; or to try to conform to the dominant model so that one 'gradually develops the form of identity and comportment characteristic of participants in this kind of practice' (Tully, 2002, p. 223). In the former case we have straightforward exclusion; in the latter we have formal inclusion but actual exclusion, for actors are included but denied the voice to challenge the dominant model. According to Welsh, for example, by modelling deliberation on 'direct communication', in which 'explicit reasons' are exchanged in response to 'specific objections' as part of a cooperative dialogue, deliberativists place 'burdensome limitations' on democratic actors. One such burden is having to run the risk of 'taking the bait', that is, of 'falling into the trap of speaking in the precise terms of one's opponent' and thereby yielding 'important conceptual and political ground' (2002, p. 686). ${ }^{1}$ Another is that, by preventing democratic actors from 'deploying rhetorical means in the face of "well- 
institutionalized" publics', deliberativists stymie democratic struggles to effect change in the legitimizing background culture. ${ }^{2}$

Given the commitment to inclusive processes, deliberation needs to be reconceived in a more expansive way. Failure to do so will leave deliberative theory vulnerable to the charge of leading to unjust exclusions, in the form of what Tully calls the 'unfreedom of assimilation' (2002, p. 223) or what Young refers to as 'internal exclusion' (2000, p. 55).

\section{The Supplementing Approach}

Recent attempts to 'rehabilitate rhetoric as a legitimate component of deliberation' have been made largely in response to the UEC (Chambers, 2009, p. 325). By seeking a place for rhetoric within deliberation, deliberativists seek an account of public deliberation that is 'more expansive in the kind of communication it allows' (Dryzek, 2000, p. 1).

Thus, in concert with critics of traditional deliberative theories, Bohman (1996, pp. 44-45) rejects any 'overly rationalistic' approach which 'unnecessarily narrows the range of convincing reasons in ways that are especially problematic for vibrant political deliberation in pluralistic societies'. Instead, Bohman sets out an account of public deliberation that includes 'the use of argument and rhetoric' and 'jarring speech acts', such as irony and jokes (1996, pp. 7, 205). Bohman points to the important role such forms of communication can play in helping social actors break through 'community-wide biases' that prevent marginalised groups from introducing new themes for public deliberation and drawing attention to unrecognised needs (1996, p. 205). Similarly, Guttmann and Thompson suggest that rhetoric can enable members of marginalised groups - whose interests are often systematically ignored - to place issues onto the deliberative agenda. Discussing Carol Mosley-Braun's impassioned performance on the floor of the US senate over the decision to renew the patent of the Confederate flag insignia, for example, they describe how her 'oratory of impassioned tears and shouts' helped reach an otherwise deaf audience (1996, p.135; 2004, pp. 50-51). Likewise, for Dryzek, 'rhetoric plays an important role in deliberating across difference' (2000, p. 167). Dryzek outlines two ways in which this is so. Firstly, rhetoric can facilitate public deliberation across differences between differently situated social actors. Dryzek refers to the appeals made by Martin Luther King Jr., whose success in reaching into the hearts of white Americans 'was aided ... by the accompanying rhetoric'. Secondly, rhetoric can facilitate public deliberation across differences between the public sphere and the state. As Dryzek puts it: 'rhetoric plays an especially important function as a transmission mechanism', given the aim to reach state actors who hold 'frames of reference initially very different from ... discourse generated within the public sphere' (2000, pp. 52-54).

The aim to rehabilitate rhetoric in deliberative theory is to be welcomed. However, I shall argue that, within the rhetorical turn just outlined, rhetoric is conceived merely as a supplement to deliberation. ${ }^{3}$ On this conception, rhetoric is what social actors resort to in particularly difficult situations. It is not a legitimate component of deliberation itself. My claim is that, firstly, this supplementing approach characterises one form of the rhetorical turn in deliberative theory and that, secondly, this approach fails to provide an adequate answer to the UEC.

Returning to Bohman, we can see this supplementing approach at work when he describes rhetoric as the form of communication speakers 'resort to' when 'deliberation fails' or is 'blocked'. It is during these 'critical junctures', where actors are 'deceived by their own ideologies and other self-deceptions' or where 'community-wide biases' entrench forms of exclusion, that one has 'recourse to other means of achieving understanding [my emphasis]'. Rhetoric is then employed with the aim of 'restoring the conditions' for deliberation or 
'restarting stalled processes of...deliberation [my emphasis]' (1996, pp. 199-206). As we have seen, Guttmann and Thompson attempt to rehabilitate rhetoric by pointing to the impassioned oratory of Mosley-Braun. But the way in which they describe her speech strongly suggests that it is not to be considered a component of deliberation, but rather a step toward deliberation. Mosley-Braun's speech, the authors claim, 'provoked deliberation' and 'stimulated debate'. The senator had to 'resort' to the 'high drama' of passionate oratory as a 'nondeliberative' step to deliberation (1996, p.135; 2004, p. 51). ${ }^{4}$ Likewise, Dryzek presents rhetoric as among 'additional' modes of communication or 'supplements' (2000, p. 76). What is supplemented is rational argument, which, Dryzek contends, 'always has to be central' to public deliberation. In contrast, the status of these supplements is 'a bit different': they are conceived of as optional extras which 'can be present' in deliberation, but need not be (2000, p. 71). This supplementing approach, then, works with a picture of public deliberation in which rational argument is separate from, and crucially untouched by, the rhetorical. The former remains the central core of public deliberation, the latter a mere appendage. ${ }^{5}$

There are two problems with the supplementing approach. Firstly, it offers a 'restricted rhetoric' (Ricoeur, 2003, p. 9), understood merely as a matter of style - the outer garments of captivating speech that orators use to grip an otherwise deaf audience. The restrictive aspect of this conception of rhetoric can be shown by contrast with a more expansive conception. In Aristotle's view, notably, a central element of rhetoric is logos, understood as seeing what is persuasive in each case and showing (deixis), through arguments (enthumèma), the persuasive grounds for opinion $\left(2009,1354 \mathrm{a} 14-29\right.$; 1354b2-22; 1355a3-18). ${ }^{6}$ From this perspective, to conceive of rhetoric merely as a supplement to rational argumentation is to make the very same mistake that Aristotle charged his own predecessors of having made, namely, of focusing on 'accessories' (prosthêkai) to rhetorical persuasion, rather than the 'body' (sōma) of such persuasion (that is, the enthymeme) (2009, 1354a15-16). For his part, Cicero rejects such an approach in still more colourful terms: as an 'unprofitable and reprehensible severance between the tongue and brain' (Fontana, 2005, p. 51).

Secondly, it is problematic for deliberative theory to respond to the UEC by presupposing an essential distinction between rational argumentation and rhetoric. For, this is to assume precisely the picture that critics challenge. As Young puts it: 'because rhetoric is an aspect of all discourse, the temptation should be resisted to base a theory of deliberative democracy on a notion of non-rhetorical speech that is coolly and purely argumentative' (2000, p. 64). ${ }^{7}$ Young's claim that 'all discourse' has a rhetorical dimension (she also describes rhetoric as an aspect of 'all speech acts' and 'every communicative effort' [p. 66]) implies that not only can rhetoric not be sidelined to a mere supplement of democratic deliberation, but that it cannot be excluded from a general theory of language. And many rhetoric theorists agree with this more universal thesis. ${ }^{8}$ Bender and Wellbery offer one of the more radical versions of this claim when they argue for what they call 'rhetoricality', that is, 'a generalized rhetoric that penetrates to the deepest levels of human existence' (1990, p. 25). So understood, rhetoric is not 'a specialized technique of instrumental communication', but 'a general condition for human experience and action' (1990, p. 38). ${ }^{9}$

By presenting rhetoric merely as a supplement to rational argument, and by setting up the latter as a normative standard that remains untouched by the former, deliberativists assume the very framework that generates the problems associated with the UEC in the first place. If we accept Young's point that rhetoric is an aspect of all discourse, however, we are still left with a problem that the supplementing approach rightly identifies and aims to address. This is the problem of how to circumscribe the legitimate role that rhetoric can play within democratic deliberation. This is why Dryzek, while attempting to accommodate the demands of critics, assures Habermasians that he is not opening the doors of deliberation and offering an unconditional 'let them in!' (2000, p. 98). Dryzek's assurance that deliberation would still 
be 'answerable to reason' is meant to address 'Habermasian antipathies to deception, selfdeception, manipulation, strategizing, and coercion' (2000, pp. 54, 67). And herein lies the tension that the supplementing approach fails adequately to resolve: how to develop a deliberative theory that affords rhetoric a legitimate role, but without giving up these Habermasian antipathies. By accommodating rhetoric as a mere supplement to deliberation, however, deliberativists fail to admit rhetoric as a legitimate component of deliberation. This failure leaves the supplementing approach with a restrictive conception of rhetoric, and an inadequate answer to the UEC.

\section{The Systemic Approach}

There is, however, another variant of the rhetorical turn in deliberative theory: the systemic approach. One of the attractions of this alternative is that it significantly weakens the normative criteria for the kinds of political speech that can be included in public deliberation. Rather than evaluating political speech according to categorical criteria based on a rationalistic conception of deliberation, the systemic approach evaluates political speech according to its overall effect on the deliberative system. As the authors of the key text of this approach put it:

A systemic approach ... allows us to conclude that a single part, which in itself may have low or even negative deliberative quality on one of the several deliberative ideals, may nevertheless make an important contribution to the overall deliberative system (Mansbridge et al, 2012, p. 3).

This significantly expands the modes of communication that could count as legitimate parts of public deliberation. Modes we would reject as violating deliberative ideals in specific instances would count as legitimate where they benefit the system as a whole. Accordingly, the task is to assess the function of political speech in terms of the system as a whole. Thus, even 'highly partisan rhetoric' that violates principles of mutual respect and accountability is deemed legitimate, where it has net systemic benefits (Mansbridge et al, 2012, pp. 3, 19). ${ }^{10}$ If the UEC calls for a more expansive notion of deliberation that remains normatively guided, the systemic approach appears to provide the answer. ${ }^{11}$

I shall focus on the approach Dryzek develops in his later work, since he specifically addresses the role of rhetoric from a systemic perspective. In contrast to his earlier advocacy of the supplementing approach, Dryzek now drops the Habermasian insistence that 'rhetoric stops at reason's door' and argues instead that rhetoric should answer to the deliberative system as a whole (2010, p. 323). When judging the proper place of rhetoric in deliberation, we should apply 'systemic tests' that track the consequences any particular use of rhetoric has for the deliberative system as a whole. As Dryzek puts it: 'the key test is, does the rhetoric in question help constitute an effective deliberative system?' (2010, p. 320). From this, Dryzek draws radical implications. While Rawls and Habermas 'are reluctant to allow that its [rhetoric's] non-logos aspects can ever substitute for reason', Dryzek argues that 'the systemic view developed here shows that such a substitution can sometimes be fruitful' (2010, p. 322). Dryzek previously rejected the latter as effectively abandoning the deliberative approach. But once we shift to systemic tests, for Dryzek, èthos or pathos may legitimately replace logos. ${ }^{12}$

This systemic approach is certainly a move beyond the supplementing approach. However, it evidently comes with significant costs. 'Categorically ugly rhetoric,' Dryzek argues, is welcomed if it 'produces good systemic results' (2010, p. 322). Discussing the extreme 
rhetoric of Australian politician, Pauline Hanson, Dryzek writes:

She had little in the way of commitment to any categorical deliberative norms, and was not averse to racial stereotyping. Yet the net result of her activities was a more deliberate polity, at least in the sense that a number of discourses that were either taken for granted or had yet to crystallize or had been marginalized took shape in a way that could have allowed for their engagement in the public sphere (2010, p. 334).

This is a puzzling place for a deliberative democrat to be in. Recall that the UEC is directed at deliberative theory's model of rational argumentation which, critics argue, leads to the unjust exclusion of certain voices from deliberation and, in so doing, violates deliberative ideals of equality, mutual respect, and democratic legitimacy. While the supplementing approach failed to open the door wide enough, the systemic approach seems to remove the door from its hinges. By focusing on net benefits, the systemic approach accepts speech that may contribute to, or entrench, pockets of 'political poverty'. ${ }^{13}$ While Hanson's rhetoric is admitted for its (perceived) net contribution to the deliberative system, one wonders what those targeted by Hanson's rhetoric would make of this.

Consider the concerns one may have regarding the rhetoric used by Nigel Farage, the former leader of the UK Independence Party. ${ }^{14}$ Even if this rhetoric - about British people feeling uneasy hearing foreign accents on public transport or having Romanians move next door - gives voice to a 'previously marginalised discourse' and stimulates a 'countermobilisation'(Dryzek, 2010, p. 334), ${ }^{15}$ it is very plausible that the price of any purported systemic benefits will appear too high to those on its receiving end. It is not clear why news that the deliberative system as a whole benefits from such rhetoric ought to persuade those directly suffering the effects of that rhetoric not to return their democratic ticket. One of the likely local effects of such rhetoric is to perpetuate political poverty. Thus, Tyler (2013) convincingly shows how extreme rhetoric directed at Travellers and Gypsies by elements of the British media and politicians created conditions that led not only to specific instances of political poverty, but to psychological suffering and physical intimidation and violence. Tyler notes how the culminating event of this extreme rhetoric - the mass eviction of Travellers and Gypsies from Dale Farm in Essex in 2011 - produced counter-mobilisations that have created solidarity between Travellers and Gypsy groups and activists across the political system and, with that, the promise of resistance to exclusions in the future. Even if one accepts that resulting counter-mobilisations guarantee a net reduction in political poverty across the system as a whole, it is not obvious why those suffering in particular pockets of the system ought to accept their suffering as a justifiable cost.

The systemic approach, then, admits discourses that, in specific parts of the system, contribute to instances of political poverty. At the very least, this result is in prima facie tension with the ideals that, as deliberativists of various stripes agree, are constitutive of deliberative democracy. ${ }^{16}$ One might try to ease this tension by appealing to categorical criteria when judging certain forms of rhetoric. But again such tests would most likely exclude the kind of communication that can help actors escape political poverty. Indeed, as I have emphasized, avoiding categorical exclusions is a key motivation of the systemic approach in the first place. Consider the case of Frederick Douglas's speeches aimed at promoting the abolitionist cause. Douglas rejected demands to 'argue more and denounce less' and instead insisted on 'scorching irony' and a 'fiery stream of biting ridicule', for 'it is not light that is needed, but fire' (Frank, 2009, p. 58). While the fire of Douglas's rhetoric would be welcomed from a systemic perspective, it would be condemned on categorical grounds. The systemic approach is right to reject categorical tests if deliberative theory is to avoid the UEC. But, while the systemic approach avoids, in one way, the UEC, by opening up 
deliberation to all kinds of political speech, it ends up throwing the deliberative baby out with the categorical bathwater. And in doing so, it remains vulnerable to a variant of the UEC: voices are excluded by accepting forms of speech that are likely to produce or entrench pockets of political poverty within the system.

Let me summarise our discussion so far. I have assessed two forms of the rhetorical turn taken by deliberativists in response to the UEC. The supplementing approach fails insofar as it casts 'alternative' modes of communication as mere supplements, suitable only for situations of deliberative breakdown. The systemic approach, in contrast, attempts to eliminate unjust exclusions by replacing categorical with systemic criteria. But this move sacrifices core deliberative ideals, not least the ideal of equality of deliberative standing. The systemic approach, as it stands, does not escape unjust exclusions. Rather than resulting from overly restrictive ideals of rational argumentation, unjust exclusions now result from forms of speech that are judged to offer systemic benefits, even where these are likely to exclude actors struggling in particular parts of the system. Unjust exclusion in the form of political poverty is a cost that deliberativists ought to be unwilling to accept.

\section{The Constitutive Approach}

We need a response to the UEC that admits rhetoric into public deliberation in a way that avoids, on the one hand, the narrowness of the supplementing approach and, on the other hand, the unrestrictiveness of the systemic approach. This in turn requires normative standards that are neither unjustly exclusionary (as is the case with categorical criteria) nor excessively open (as is the case with systemic criteria). Aristotle's constitutive account of rhetoric can help with this task. By 'constitutive' I do not mean the process of rhetorically constituting the subject-as-audience, as developed by Charland (1987). Rather, I mean to highlight, firstly, that èthos, pathos, and logos are constitutive elements of rhetoric and, secondly, that rhetoric (so understood) constititues political judgement. I shall argue that Aristotle's constitutive account of rhetoric opens up deliberation in a way that avoids the problems associated with the supplementing approach. In addition, by conceiving rhetoric as an art (technē) with internal standards, Aristotle's approach avoids some of the unwelcome consequences of the systemic approach.

In designating rhetoric as a 'counterpart [antistrophē] of dialectic' Aristotle sets out an account of rhetoric that directly challenges the restricted conception of the supplementing approach $(2009,1354 a){ }^{17}$ Dialectic is the capacity to examine arguments and, through strict and rigorous reasoning, to show the way from opinions towards the starting points of knowledge. As a counterpart, rhetoric is the capacity to see what is persuasive in each case and, through enthymemes and examples, to show the persuasive grounds for opinion. Rather than being mere accessories that orators drape around the body of reason, rhetoric is persuasive speech whose body consists of 'providing arguments' $(2009,1356 a 34) .{ }^{18}$ But there is a difference with dialectic, hence the term 'antistrophe'. Unlike dialectic, which reasons about that which admits of certain knowledge, rhetoric is located within a deliberative situation, where 'things admit of going different ways' (2009, 1356a8-9; 1357a.5-6). To use a Socratic image, while the movement of dialectic is an ascent out of the cave of opinion into the sunlight of knowledge, rhetoric is a descent into the cave of a particular community, where citizens struggle, in the flickering 'firelight of opinion', with questions about the just, the advantageous, and the beautiful for their political community (Sachs, 2009, p. 19). So, although rhetoric is a theoretical activity of seeing and showing the persuasive grounds for opinion in the matter at hand, it is neither detached nor separable from our emotional orientation to the world of our concern. And knowing how the emotions, 
commitments, and evaluations of her fellow citizens can affect judgement is something a speaker cannot ignore if she is to see and show her listeners persuasive grounds for opinion in each case. ${ }^{19}$ It is for this reason that Aristotle describes rhetoric as an 'outgrowth' (paraphues) of dialectic into politics $(2009,1356 \mathrm{a} 27-29 ; 1359 \mathrm{~b} 11)$.

Understood as such an outgrowth, the way the art of rhetoric engages the emotions is no mere last resort because of an irrational or deaf audience. ${ }^{20}$ Rather, the emotions play a constitutive role in judgement because of the complexity and indeterminacy of the deliberative situation (Garver, 1994, p. 109-10), in which arguments are presented by a particular speaker to a particular audience on some matter of concern which admits of going different ways. That is to say, the deliberative situation is one in which we are called upon to exercise judgement on issues that matter to us, in light of arguments that appear convincing to us. 'Rhetoric', Aristotle observes, 'is for the sake of judgement' (2009, 1377b21). And given that the 'emotions are those things through which, by undergoing change, people come to differ in their judgements' $(1991,1378$ a), they are a constitutive element of the deliberative situation, rather than a mere accessory. ${ }^{21}$ The judgement we eventually arrive at in a particular situation will depend on how we perceive that situation and experiencing the appropriate emotions is crucial if it is to be properly perceived as a situation that matters to us. $^{22}$

The complexity and indeterminacy of the deliberative situation is also the reason why $\bar{e}$ thos is a constitutive element of public deliberation:

But since rhetoric is for the sake of judgement...it is necessary not only to look to the argument...but also to present oneself as a certain sort of person...for it makes a big difference as far as persuasion is concerned, in deliberations especially,... what sort of person the speaker appears to be...(2009, 1377b21-29, emphasis mine).

Just as the emotions of the audience affect how things appear to them, and thus the judgements they make concerning the arguments presented to them, so too will the character of the speaker, qua speaker, affect the way a speaker's arguments appear to them. In Aristotle's account, the speaker being trustworthy (axiopiston) is crucial. In pointing to judgement (phronēsis) and virtue (aretē) as two elements 'on account of which we feel trust' (the third is goodwill [eunoia]), Aristotle's account of êthos has, accordingly, an epistemic and an ethical dimension. Two of the ways in which trust can be lost makes this clear: 'they [speakers] either have incorrect opinions on account of lack of judgment, or while they have correct opinions they do not say what seems true to them on account of vice' $(2009,1356 a 5$ $9 ; 1378 \mathrm{a} 6-17){ }^{23}$ If the audience judges the speaker to have failed in either dimension, the speaker's arguments will fail to have probative force.

It is salutary to note, however, that the centrality of ethos to public deliberation does not leave us lost in the cult of personality. Recall that logos is the body of persuasion and that persuasion through èthos (as well as pathos) is legitimate only where it is made through argument. Aristotle insists that persuasion through character 'ought to come about through the argument [dia tou logou], not because the speaker has a prior reputation for being a certain sort of person' (2009, 1356a9-11, translation modified). Persuasion through èthos is to be achieved not by listing one's past triumphs, but by exhibiting one's character through argument (Cooper, 1994, pp. 197-8; Farrell, 1993, p. 80). ${ }^{24}$

While Habermasians are right to emphasise the force of the better argument, I submit that the real significance of the rhetorical turn in deliberative theory is that ' $[t]$ he force of an argumentation is always relative [to the specific audience]' (Manin, 1987, p. 353; cf. Perelman 1982, p. 9ff; Beiner, 1983, p. 85). And given this, the rhetorician cannot afford to ignore pathos or $\bar{e}$ thos if her arguments, as presented in a deliberative situation, are to be 
persuasive to her audience. To recall Abizadeh's formulation of this constitutive approach: we should understand 'the role of the three pisteis conjunctively: the art of rhetoric requires that éthos, pathos, and logos operate every time' (2002, p. 274).

\section{The Manipulation Problem}

But one can already hear Gorgias at the door. If rhetoric, understood according to the constitutive approach, is admitted as a legitimate component of deliberation, then how are we to avoid the dangerous kind of rhetoric that merely manipulates the audience? While Gorgias's description of rhetoric, as a 'force of incantation' which 'by entering into the opinion of the soul...is wont to beguile...and alter it by witchcraft', may not strike us with quite the force that it once did $(2009, \S 10)$, Kant's image of rhetoric as 'an insidious art' that moves men 'like machines to a judgment' and thus 'robs their verdict of its freedom' is still very much with us $(1953, \S 53){ }^{25}$ The question, then, is whether the constitutive approach provides a principled distinction between manipulative and non-manipulative practices. ${ }^{26}$ If it does, then this would answer the worries which motivate the supplementing approach, while justifying a more inclusive approach of the sort advocated by defenders of the systemic approach.

A key argument of Aristotle's is that rhetoric is an art (technē). While this is a seemingly dry, academic point, what is at issue here is the 'politics of demagoguery' (Garsten, 2006, p. 129). If rhetoric is not an art, then it does not have technical standards internal to that practice to guide it. In the absence of such standards, the speaker is free to deploy whatever knack (empeiria) to help her achieve her goal of winning her audience over. Imagine someone who wins a game of pool by randomly hitting the balls and distracting her opponent when the latter is taking a shot. While this player achieved the goal of winning the game, we would hardly describe them as having engaged in the art of pool. However, we may describe her opponent in these terms, despite having lost. And we would do so by judging how well the opponent played the game in reference to standards internal to the art of pool (e.g. she showed skill in reading the table, displayed good judgement in shot selection, demonstrated sound positional awareness, etc.). If rhetoric is a techne, then the rhetorician - like any practitioner of an art - will be guided by standards internal to the art, rather than external standards. This does not mean that the goal of persuading the audience drops out of the picture for the rhetorician, any more than the goal of winning the game drops out for the pool player. As Garver notes, 'unless achieving the external end were desirable, no one would even develop an art' (1994, p. 28). Rather, the point is that the rhetorician will be guided by, and judged in reference to, standards internal to that art. Garver (1994, p. 24ff) helpfully distinguishes between a 'guiding end' (which is 'constitutive' of an art) and a 'given end' (which is 'external' to an art):

Every art...has two ends. Activities for which there is no corresponding art have only one end, achieving the external, given good...Some activities, those with only an external end, are...complete only when they are over and successful. Other activities, those with guiding ends, aim at a good outside themselves but also answer to internal standards of completion and perfection (Garver, 1994, p. 28).

So, when Aristotle counter-intuitively insists that rhetoric's 'work [ergon] is not to persuade but to see the means of persuasion that are available on each matter' $(2009,1355 \mathrm{~b} 10-11)$, he is shifting the normative standards of the practice: from the external, non-technical goal of winning, to the internal, technical standard of seeing the available means of persuasion. With 
this shift, rhetorical success is no longer evaluated by reference to the external, given end of winning, but by the internal, guiding end of discovering the best available means of persuasion in the particular situation. It is this normative distinction that provides the ground for Aristotle's attack on his predecessors (Garver, 1994, ch. 1).

It is because they looked solely to the external, given end of winning, that Aristotle charges his predecessors of focusing on practices that are 'not even...part of the art' (2009, 1354a13). When his predecessors outline ways to causally move an audience through appeals to the passions, Aristotle argues that they:

busy themselves with things that are extraneous to the matter at hand; for prejudice and the passions of the soul such as pity and anger are not concerned with the matter at hand...one ought not to lead the juror astray by provoking....anger or envy or pity, since that would be as if someone made the very thing crooked that he was about to use as a ruler $(2009,1354 \mathrm{a} 14-27)$.

Two points are needed here. Firstly, this may seem to contradict the claim that the pathe are essential to rhetoric. But it does not. ${ }^{27}$ Aristotle's predecessors go wrong not by appealing to emotions, but by focusing on the atechnical practice of simply manipulating emotions to causally bring about their desired decision. Recall, that to engage in the art of rhetoric, a speaker will be directed by the guiding end of seeing the available means of persuasion in the matter at hand. And, as we have seen, on the constitutive approach, those means are the 'technical proofs' (entechnoi pisteis) of èthos, pathos, and logos (2009, 1355b35), which conjointly operate every time. In addition, these proofs must be demonstrated 'through the argument [dia tou logou]' (2009, 1356a9-11). Aiming straight for the external end of getting one's desired decision, and attempting to achieve this through such manipulatory strategies, circumvents both requirements and therefore fails as an exercise in rhetorical expertise.

Secondly, as well as being guided by the internal end of seeing the available means of persuasion, the rhetorician needs to show her audience those means. The reason for this is, as noted above, that 'rhetoric is for the sake of judgement' $(2009,1377 \mathrm{~b} 2)$. The rhetorician must show her audience the available means of persuasion to help them arrive at a judgement. I suggest that this is not just any judgement, but a well-grounded judgement. ${ }^{28}$ Above I described the 'means of persuasion' as 'proofs'. The term Aristotle uses here, pisteis, is often translated in both ways. But while the singular, pistis, is related to peitho (to persuade), it is a distinct concept (it can mean 'trust', 'credence', 'credit'). ${ }^{29}$ When Aristotle charges his predecessors with failing to say anything about the art of rhetoric, he explains: 'for the means of persuasion [pisteis] alone are intrinsic to the art' $(2009,1354 \mathrm{a} 14)$. If rhetoric is for the sake of judgement, and if the rhetoricians' role is to see and show her audience pisteis relevant to the particular matter, then the task of the rhetorician is nothing more, but nothing less, than providing her audience with 'proofs' that serve as credible grounds for judgement. As Aristotle insists, 'there is nothing appropriate...to do outside of showing' (2009, 1354a2728). In taking these pisteis as credible grounds for judgement, the audience must understand themselves to be doing just that: taking the pisteis as providing them with good grounds for their particular judgement. As Garver argues, "proof depends on the hearer recognizing what a speaker is doing. I cannot prove something to you unless you realize that that is what I am doing' (1994, p. 38). And to be a process of persuasion it:

has to be intentional and require this mutual awareness, because belief...is similarly intentional. Pistis is best rendered here as trust: You can arouse my indignation without my knowing that this is what you are doing, but I cannot trust you without being aware 
that I am trusting you. Making the audience do the speaker's bidding because he has made them indignant is in this sense not persuasion (Garver, 1994, p. 153).

Persuasion presupposes what Garsten calls the 'active independence' of the audience. Despite the passive voice, Garsten observes that when "someone...decides, "Alright, you have persuaded me," he is not merely describing something that has happened to him...he is describing something he has done' (2006, p.7; cf. Aristotle, 2009, 1554a30-1). If mutual awareness and active independence are essential aspects of showing an audience the relevant pisteis, then causally moving an audience by manipulating their emotions would not be an exercise of rhetorical expertise. Such a practice not only fails to show any credible grounds, but it depends on concealing one's intention and, a fortiori, destroying mutual awareness and undermining the active independence of the audience, both of which are crucial for seeing and showing an audience credible grounds for the sake of good judgement. On the predecessors' approach, this would be warping and coercing the audience for the sake of winning.

On the constitutive approach, then, the kinds of manipulative tactics that worry advocates of the supplementing approach would remain outside the art of rhetoric. In addition, such an approach would prohibit dangerous forms of rhetoric that would be admitted by defenders of the systemic approach.

One might object that the constitutive approach does not provide a principle that would clearly demarcate manipulation from non-manipulation. Moreover, Aristotle's Rhetoric seems an unlikely place to find such a principle. While providing resources for the constitutive approach, the Rhetoric seems also to provide resources for less reputable practices. ${ }^{30}$ I agree with both points, and will briefly address each, taking the latter point first.

Numerous attempts have been made to address the manipulation problem in the Rhetoric. Some commentators deploy a version of the ideal/normal rhetoric distinction (see n.27) and argue that Aristotle, in the name of political efficacy, adopts 'a pragmatic attitude' (Sprute, 1994, p. 127) when it comes to less-than-ideal conditions. Others identify epistemic and/or moral principles that serve as constraints. ${ }^{31}$ None of these responses are entirely satisfactory. Indeed, when Aristotle considers the manipulation problem, he seems to concede the point:

As for the claim that someone using such a power with speeches might do great harm, this applies in common to all good things, except virtue, and most of all to the most useful things, like strength, health, riches, and skill at leading armies; for one might confer the greatest benefits by using these justly and do the greatest harm using them unjustly $(2009,1355 b 3-8)$.

Although rhetoric, as a techne, has guiding ends with their own internal standards of evaluation, these standards do not provide a principle to solve the manipulation problem. And the reason for this is because "sophistry is present not in the power but in the intention [proairesis]' (2009, 1355b17-18). And if there is no neutral principle that we can apply to track intentions, then the search for a principle to solve the manipulation problem is doomed:

If the difference is not one of art but motive, then there are no aspects of the art that cannot be used sophistically for external purposes. There is no distinction between rhetoric and sophistic, only between the rhetorician and the sophist. Everything the rhetorician does artfully, the sophist can also use for ulterior motives (Garver, 1994, p. 222). 
This does not mean giving up on the manipulation problem; it means giving up on the search for principles. The constitutive approach provides an account of non-manipulative rhetoric and the normative standards internal to the art. But, empirically distinguishing a rhetorician from a sophist will be a matter of judgement. While there will be paradigm cases of manipulation, we will mostly face difficult cases. Such cases will not be decided by the disengaged theorising of the deliberative theorist; they will be first-order questions for deliberators.

While the internal standards of the art of rhetoric could help identify some forms of manipulation, difficult cases will require êthos-based judgements. ${ }^{32}$ As Garver suggests above, the judgement we need to make is not between rhetoric and sophistic, but 'between the rhetorician and the sophist'. Recall, that èthos-based judgements concern èthos qua speaker, rather than direct appeals to character. When the former White House Communications Director, Anthony Scaramucci, was asked about 'credibility' and whether he would 'give accurate information and truth', his response - 'I feel like I don't even need to answer that question...that's the kind of person I am' - was a direct appeal to èthos, rather than a display of éthos qua speaker (Fox10, 2017, at 11:14-40 mins). But how would one arrive at an èthos-based judgement, qua speaker? Garver provides a helpful suggestion:

The principal thing I would have to point to would be...the logos of the speech. It is the primary evidence for the speech's èthos. Turning attention to èthos would...change the focus slightly. The speaker's èthos would... answer such questions as: Why choose this decision and argument and not another? Why this example? Why these probabilities and signs and why weight them as you did? (Garver, 1994, p. 195). ${ }^{33}$

The manipulation problem, then, requires èthos-based judgements that look to a speaker's character as revealed through their 'pattern of deliberation and choice' (Garver, 1994, p. 195). While such judgements do not provide a principle to solve the manipulation problem, they do offer a way of approaching that problem.

One might object that this still leaves the door open to manipulative speakers. That is true. But, principles will not bar that door. Whether or not the sophist is able to trick her way in will depend largely on the audience's capacity for judgement and, specifically, 'understanding' (sunesis). ${ }^{34}$ The deliberative situation requires not only artful speakers, but an educated audience. Reeve provides helpful suggestions about the latter. In On the Parts of Animals, Aristotle states that 'it is the mark of an educated man to be able to judge successfully what is properly expounded and what is not'. In the Eudemian Ethics, Aristotle suggests that 'a lack of education [apaideusia]' will reveal itself in an 'inability to judge which reasonings are appropriate to the subject and which foreign to it' (both cited in Reeve, 1996, pp. 192-193). The capacity to judge when something is properly expounded and when reasoning is or is not appropriate to the subject is precisely the kind of skill an audience needs to exercise in a deliberative situation. Addressing the manipulation problem, then, requires looking to both speakers and listeners. The advice Aristotle offers to speakers is useful for $u s$ listeners too: we need to know how one might be persuasive about opposite things 'so that the way things are might not go unnoticed, and in order that, if someone else uses arguments unjustly, we ourselves will have the means to refute them' $(2009,1354 \mathrm{a} 32-35)$. We need not assume Aristotle's 'epistemological optimism' (Wardy, 1996, p. 60) for this; we need only assume that we modern day listeners can develop and exercise such capacities. While the socalled dark arts that Aristotle describes in the Rhetoric generate the contradiction problem, these sections of the text may help us, a modern-day audience, mitigate the manipulation problem. 


\section{Deliberative Standing}

While the constitutive account of rhetoric avoids unjust exclusions that result from invoking categorical criteria, and while it avoids sacrificing core deliberative ideals for systemic gains, it is not clear how this approach deals with the suffering of those who are targets of certain forms of extreme political speech. One can imagine speakers meeting the internal standards of the art of rhetoric and still deploying racist political speech. Such speech is likely to produce precisely the kind of suffering that I criticised the systemic approach for accepting. We therefore need to develop a response that also addresses the suffering of those who are struggling against political poverty. Again, Aristotle can help us here.

As we have seen, a crucial aspect of the art of rhetoric is knowledge of the soul of one's political community. But as Aristotle suggests, that, in turn, requires knowledge of one's political regime and, specifically, the end sought by that regime. For, the latter will shape the character of one's fellow citizens $(2009,1366 a 14-16)$. Now Aristotle notes, 'the end sought by democracy is freedom' $(2009,1366 \mathrm{a} 4)$ and its guiding principle is that of equality. What characterises the citizen in a democracy is 'his participation in judgement and authority' (1962, III.1), whether deliberative or juridical, for without such participation democratic freedom and equality cannot be realised (1962, IV.4). ${ }^{35}$ Excluded from participation, one would be like 'some interloper of no standing [timē]' (1962, III.5). To be excluded from such participation, then, is to be denied the kind of standing required to be seen, and to see oneself, as a fellow citizen. If participation in judgement and authority is essential to what it is to be a democratic citizen, then exercising that function well means that 'a good [democratic] citizen must have the knowledge and capacity both to rule and be ruled' (1962, III.5, translation modified). But that can only be gained through active participation in deliberative processes. Thus being excluded from such active participation not only denies the status crucial to one's standing as a democratic citizen, but it also denies one the opportunity to develop the knowledge and capacity through which one can gain such standing. As Rostbøll suggests (when setting out his own account of deliberative freedom):

is it not the case that democracy gives citizens such capability and such standing?...[D]iscursive capability and status are attributes that can only develop in the presence of others... It is by living in a democracy - in particular, a democracy that promotes public deliberation - that we become citizens whose opinions matter...It is as participants in deliberative politics that we have discursive status $(2008$, p. 66).

What Aristotle is identifying here, then, is what deliberativists call equal deliberative standing (Bohman, 1996, p. 104; Cohen 1997, p. 74). ${ }^{36}$ Furthermore, Aristotle emphasises, along with deliberativists, the importance of certain insights and capacities, developed through participation in deliberation, for gaining such standing (cf. Cohen 1997; Bohman, 1997; Rostbøll, 1998; Knight and Johnson, 1997). ${ }^{37}$

If the end sought by democracy is freedom, and if its guiding principle is equality, then fundamental to freedom in a deliberative democracy is participating in public discourse such that I gain equal deliberative standing and thus deliberative uptake. And this is a virtuous democratic circle: the more I participate in public deliberation, the more I develop the insights and capacities necessary to contribute to the forms of collective judgment and selflegislation constitutive of a deliberative democracy. And the more I develop those capacities and insights, the more likely it is that I will receive deliberative uptake and thus enhance my standing as a democratic citizen. ${ }^{38}$ In participating in public deliberation, I enjoy 'deliberative 
freedom' (Rostbøll, 2008; cf. Bohman, 1997). Where I am excluded from public deliberation, I fall into political poverty.

To seek to promote equal deliberative standing is to seek to protect citizens' deliberative freedom by ensuring that no citizen falls into political poverty. If a political speech either undermines the deliberative standing of citizens vulnerable to the threat of political poverty or further entrenches citizens in such poverty, then deliberativists ought to disavow such speech, as it denies citizens their deliberative freedom. In the absence of such deliberative freedom, it is hard to see how one could still talk of mutual respect, equality, and inclusion key deliberative ideals. In Aristotelian terms, we can say that the end sought by any deliberative democracy should be to cultivate, preserve, and enhance the deliberative standing of its citizens. And that means exposing any particular instance of political poverty and attacking the conditions that create or sustain it. To accept an instance of political poverty, therefore, would be to accept instances in which deliberative freedom is denied. ${ }^{39}$ Such a denial can neither be dissolved by distributing the value of deliberative standing across a system, nor compensated for by overall gains in other parts of the system.

Securing deliberative standing, then, is a way of protecting those struggling against political poverty. Following Bohman, I take 'political poverty' as a minimal 'threshold requirement', understood 'in terms of the equal capacities to participate effectively' in public deliberation (1996, p. 131). The reason for adopting this minimal approach is to avoid closing off 'critical oppositional activity' that may need to violate core deliberative ideals, such as mutual respect, in the very struggle against political poverty in non-ideal circumstances (Young, 2001, p. 671). Mutual respect is a weighted ideal: where particular forms of speech undermine the deliberative standing of those struggling against political poverty, the ideal should be taken as an immovable weight. However, this should not tie those struggling against political poverty to ideal deliberative processes that are skewed by background conditions of inequality and power. This would turn the protective immovable weight of mutual respect into a dead weight that would anchor those struggling for deliberative uptake more firmly in political poverty.

So, for example, when Westbrook, a US investment firm, bought a housing estate in London and threatened to evict tenants who were unable to pay the newly tripled rents, residents launched a vociferous campaign that involved multiple tactics, including town hall meetings with officials, exerting pressure through petitions, protesting outside Westbrook's London offices, shaming executives of the company, and threatening to occupy homes on the estate (Booth, 2014). Here is a case of weighted mutual respect. Given the inequality of power and resources, the lack of deliberative reciprocity, and the fact that efforts to open up deliberative channels with Westbrook had been exhausted, residents justifiably resorted to tactics that violated mutual respect. ${ }^{40}$ And it is precisely the inequality of power and resources, and the deliberative aims of the residents, that not only plausibly justifies this activism, but also rules out Westbrook from violating mutual respect in the reverse direction.

\section{Conclusion}

I hope in this paper to have shown how Aristotle can provide deliberativists with a more adequate response to the UEC than is possible within the terms of the recent rhetorical turn in deliberative theory, in the two forms we have considered. I have tried to draw out the ways in which the constitutive approach incorporates the strengths of the supplementing and systemic approaches, while avoiding their respective weaknesses. The constitutive approach corrects the supplementing approach by offering a more expansive conception of rhetoric, in which $\bar{e}$ thos, pathos and logos are jointly constitutive elements. Furthermore, the constitutive 
approach understands rhetoric to be constitutive of public deliberation, rather than a nondeliberative step toward deliberation. By showing how rhetoric is a techne with its own internal standards, the constitutive approach corrects both the supplementing and systemic approaches by providing normative criteria that are neither excessively restrictive (as is the case with the supplementing approach) nor excessively open (as is the case with the systemic approach). As our discussion has shown, the internal technical standards of rhetoric, alongside $\bar{e}$ thos-based judgements, provide a way of addressing the manipulation problem. And, finally, the democratic principle of deliberative standing not only provides democratic actors with the opportunity to develop the insights and capacities that will help with those ethos-based judgements, but it also protects actors from the threat of political poverty that remains with the systemic approach. The constitutive approach does not rule out judgements about systemic benefits and burdens of political speech. But, it does rule out speech that undermines one's deliberative standing and, thus, one's deliberative freedom. This is important if deliberative theory is not to lose sight of the fact that it is a critical theory, one that aims to expose any instance of (illegitimate) political impoverishment and attack the conditions that create and sustain it.

\section{Acknowledgments}

I would like to thank Fabian Freyenhagen, David McNeill, Alexandra Popescu, and two anonymous reviewers for helpful discussions and feedback. Special thanks to Dan Watts.

\section{About the Author}

Steven Gormley is a lecturer in Philosophy at the University of Essex in the UK. He has published articles on the ethics and politics of deconstruction, and the concept of forgiveness. He is currently working on a book manscript that discusses deliberative and deconstructive accounts of doing justice to the other.

\footnotetext{
Notes

${ }^{1}$ The comedian Stewart Lee made this point when criticising an approach to arts funding that reduced the value of the arts to financial value. When the interviewer suggested that cutting arts funding was wrong because many artistic productions are commercially successful, Lee responded: 'the problem with that is you're being drawn into fighting the war on their terms'. Lee argued that defenders of the arts who respond directly in their opponents' terms have 'already lost because they speak to these people as if the only point of the arts were to make money’ (Devereux \& Onians, 2010, at 33:55mins).

${ }^{2}$ Farrell (1993, p. 258ff) shows how rhetoric can help actors initiate a 'critical interruption' of an oppressive background culture.

${ }^{3}$ In later work, Dryzek and Bohman develop a systemic approach. Setting out these two approaches as independent alternative responses, however, will not only help us see what is at stake in the debate over the UEC, but will also allow me to bring out the strengths and weaknesses of each approach.

${ }^{4}$ For a critical discussion of Guttmann and Thompson see Krause (2008, p, 152-153) and Young (2000, p. 6667).

${ }^{5}$ For a critical discussion of Dryzek and Bohman's account see Norval (2007, pp. 67-72). For a proposed 'rhetorical revision' of Habermas, see Farrell (1993, ch. 5).

${ }^{6}$ As Sachs (2009, p. 289) notes, showing through enthymemes involves 'the presentation of evidence for an opinion' and this is 'the central and characteristic activity of rhetorical speaking' (my emphasis). See Garver (1994, p. 51): 'Aristotle's great innovation in the Rhetoric is the discovery that argument is the centre of the art of persuasion' (my emphasis).
} 
${ }^{7}$ Young (2000, p. 65) also claims that rhetoric 'constitutes the flesh and blood of any political communication'. Beiner (1983, p. 96) too argues that rhetoric cannot be 'restricted to instrumental employment' but, instead, 'bears a constitutive relation to political judgement and deliberation'. For similar 'constitutive' arguments, see, Abizadeh (2002); Fontana, Nerderman and Remer (2005); Garver (1994); Garsten (2006); Remer (1999); Rorty (1996); Yack (2003).

${ }^{8}$ Hauser (1995, p. v) notes how many rhetoric theorists now argue 'that rhetoric is inherent in all language use'. Meyer (1994. p. 121) argues that 'rhetoric is an inherent dimension of any linguistic activity'. Schiappa (2001) provides a helpful summary of some of the variations of this 'universalisation' of rhetoric.

${ }_{9}^{9}$ Assessing this universalisation of rhetoric goes beyond the scope of this paper. Schiappa (2001) provides a helpful discussion of rhetoric theorists critical of universalisation. Perelman (1982, p.162) takes a middle path, suggesting that 'the realm of rhetoric' expands beyond the merely ornamental use of language to cover 'any discourse which does not claim an impersonal validity'.

${ }^{10}$ Cf. Bohman (2012, pp. 84-85): 'a systems approach suggests that the reduction of bias overall is the proper goal for the system as a whole.' As such, 'we do not need to idealize deliberation in each dimension... but rather test the deliberative system as a whole and how well it functions according to a basic list of democratic functions'.

${ }^{11}$ For an excellent critical survey of the systemic approach see Owen and Smith (2015).

${ }^{12}$ Although Dryzek draws on Aristotle, this separation of the three proofs (pisteis) of rhetorical persuasion misses Aristotle's insistences that logos is the 'body' of persuasion. Aristotle (2009, 1356a1-20) insists that all three forms of persuasion are made through argument (dia tou logou). Were this not so, such persuasion would remain an atechnical practice of merely moving the audience through an appeal to the passions $(2009,1354 \mathrm{~b} 16-$ $23 ; 1355 \mathrm{~b} 36)$. Abizadeh $(2002$, p. 274) persuasively argues that we should understand the role of the three pisteis conjunctively: the art of rhetoric requires that ethos, pathos, and logos operate every time'. See also Beiner (1983, pp. 96-97), Brunschwig (1996, p. 46); Cooper (1994, p. 197); McCabe (1994, pp. 143-147).

${ }^{13}$ Bohman (1996, p.110): 'Political poverty designates a failure of capacity in public deliberation [...] In order to be minimally effective in deliberation, a deliberator must be able to initiate public dialogue about an issue or theme, in which his or her reasons may receive deliberative uptake. Just as economic agents must have the capacity to avoid acute hunger and malnourishment, so too public actors must have the ability to avoid being excluded from public life and to avoid having their concerns consistently ignored'.

${ }^{14}$ Farage offered a systemic-sounding defence of campaign posters in 2014, which many regarded as reproducing the racist rhetoric of the British National Party: 'The posters are... going to get people talking. I'll have a little bet with you...there'll be pubs and clubs and restaurants up and down this country tonight where a big conversation will be going on' (Wintour and Collier, 2014).

${ }_{15}^{15}$ Dryzek is not discussing UKip but net benefits more generally.

${ }^{16}$ Manbridge et al (2012, pp. 11-13) insist that a primary function of the deliberative system is to 'produce mutual respect among citizens'. For, mutual respect 'is intrinsically part of deliberation' linked, as it is, to the moral status of citizens as co-authors and to non-domination.

${ }^{17}$ The term 'antistrophe' is 'a stanza in a choral ode in the same metric meter as the preceding stanza, and dances in the same steps, but in the opposite ... direction across the stage' (Sachs, 2009, p. 113, n.1).

${ }^{18}$ See Cooper (1994. p. 197); Garver (1994, p. 51); Kennedy (1991, p. 34); McCabe (1994, pp. 139-141); Sachs (2009, p. 289).

${ }^{19}$ As Aristotle observes, 'we do not render our judgements the same way when grieved as when delighted' (2009, 1356a13-15; cf. 1377b32-35; 1378a19-22).

${ }^{20}$ Various commentators on Aristotle adopt this supplementing view. See Sprute (1994, p. 122); Schütrumpf (1994, p. 115).

${ }^{21}$ Aristotle does not take the emotions to be mere brute causes of judgements: 'And when people believe they themselves are in the wrong and suffering justly no anger arises...since they no longer regard themselves as being treated inappropriately, and that is what anger was taken to be' $(2009,1380 \mathrm{~b} 15-18)$. Similarly, we feel pity when an evil 'strikes someone who does not deserve it' (1385b12-14). For a defence of the emotions being constitutive of deliberative judgement see, Abizadeh (2002, pp. 275-279); Beiner, (1983, p. 96); Cooper, (1994, p. 198); Gartsen (2006, p. 122); McCabe (1994, p. 159); Nussbaum (1990, p. 80); Wardy (1996, p. 63).

${ }^{22}$ Nussbaum calls this the 'inclusive view of perception' (1990, p. 80).

${ }^{23}$ Goodwill is discussed under the pathe $(2009,1378 \mathrm{a}$ - -17$)$.

${ }^{24}$ For a detailed defence of êthos being constitutive for public deliberation, see Garver (1994).

${ }^{25}$ Benhabib (1996, p. 83): 'Rhetoric moves people and achieves results without having to render an account of the bases upon which it induces people to engage in certain course of actions rather than other'. Kant's horror seems to have been fully realised: 'On its website, Cambridge Analytica makes the astonishing boast that it has psychological profiles based on 5,000 separate pieces of data on 220 million American voters - its USP is to use this data to understand people's deepest emotions and then target them accordingly. The system, according to 
Albright [a professor of communications at Elon University] amounted to a "propaganda machine" (Cadwalladr, 2017).

${ }^{26}$ Below I suggest that seeking principles is misguided.

27 The contradiction problem has generated a vast amount of literature. Some argue that the contradiction dissolves once we realise that the account of rhetoric offered in 1.1 is different from the account offered in the rest of the text. Sprute (1994) distinguishes 'ideal rhetoric' from 'normal rhetoric' (pp. 119-121); EngbergPederson (1996, p. 122) refers to 'austere' and 'normal' rhetoric; Schütrumpf $(1994$, p. 114) contrasts rhetoric 'in its most valuable form' with how 'it is practiced'. Others (Cooper 1994, pp. 195-196; Brunschwig 1996, p. 46; Wardy, 1996, p. 64) argue that the distinction is between atechnical and entechnical appeals to the emotions. I take the latter line. For an excellent discussion of this see Dow $(2015, \mathrm{ch} .7)$.

${ }^{28}$ Dow (2015, p. 31ff): rhetoric aims at 'well-founded judgements in the listeners'; Garsten (2006, p. 190): rhetorical deliberation is 'concerned with drawing out good judgement'.

${ }^{29}$ I am grateful to David McNeill for drawing my attention to this.

${ }^{30}$ Oates (cited in Engberg-Pedersen, 1996, p. 116) offers an (overly) extreme criticism of the Rhetoric, describing it as 'a practical handbook for the instruction of public speakers in all the techniques and tricks of the trade'.

${ }^{31}$ Wardy (1996, p.66) suggests the former: 'I have argued that [Aristotle's optimism regarding] the natural prevalence of truth, its persuasive superiority, is intended to offset mistrust of rhetoric'. For Engberg-Pedersen (1996, p. 124), Aristotelian rhetoric is a 'search for factual, ethical, or political truth... a case of truth-discovery'. Iriwn (1996, p. 145) is the clearest example of the latter, arguing that Aristotle's approach 'implies that moral considerations should influence the orators decision' about the means of persuasion she adopts. Textual support can be found for both (e.g. 1355a13-40). See Dow (2015, ch. 5) for an excellent discussion of this.

${ }^{32}$ I cannot defend fully this claim here, but I take a similar approach to Garver (1994).

${ }^{33}$ The recent ridiculing of the British Prime Minister, Theresa May, as 'Maybot' - on account of her repetition of the phrase 'strong and stable leadership' - expressed a negative èthos-based judgement of her qua speaker.

34 'Exercising the faculty of opinion for the purposes of judging about another person's account of matters... [is an]...act of judging [that] is called understanding [sunesis]' (Aristotle, 1976, 1142b31-1143a16). See Halliwell (1996, p. 178).

${ }^{35} \mathrm{Cf}$. 'For where all do not participate, this is in general a mark of oligarchy' (1962, IV.6).

${ }^{36}$ Cf. Guttmann and Thompson, (2003, pp. 79-89); Rostbøll, (2008, ch. 2); Welsh (2013, ch. 3).

${ }^{37}$ This is not to claim Aristotle as a deliberative democrat. His restrictive understanding of who would qualify as a citizen makes that clear. The point is that Aristotle's thinking about what being a democratic citizen involves is helpful for contemporary deliberative theory.

38 Aristotle emphasises the importance of 'educating citizens for the way of living that belongs to the constitution in each case' and that citizens should be 'trained and have their habits formed by that politeia, that is to live democratically if the laws... are democratic, oligarchically, if they are oligarchic' (1962, IV.9 cf. III.5). If one wishes to secure a deliberative democracy, then the process outlined here would be a crucial part of the education, training, and habituation of deliberative citizens. Not only would this be a necessary requirement for achieving deliberative standing, but it would also contribute to the general education of deliberative citizens and, thus, to addressing the manipulation problem.

${ }^{39}$ Qualification is needed here. There may be cases where we might want to politically impoverish certain discourses (e.g. White Supremacist discourse). To be afforded the protections of deliberative standing, one would need to respect the deliberative standing of other democratic actors. Deliberative standing, then, would be a democratic principle that operates according to what Blaug calls the 'principle of preservation'. For Blaug, this means democrats facing up to the necessity of having to consent to the 'fairest unfair practices' (1996, p. 69).

${ }^{40}$ Residents engaged in what Fung (2005) calls 'deliberative activism'.

\section{References}

Abizadeh, A. (2002) The Passions of the Wise: Phronêsis, Rhetoric, and Aristotle's Passionate Practical Deliberation. The Review of Metaphysics, 52(2): 267-296.

Aristotle (1991) On Rhetoric: A Theory of Civic Discourse, translated by George A. Kennedy. Oxford: Oxford University Press.

Aristotle (2009) Rhetoric, Translated by Joe Sachs. Newburyport, MA: Focus Publishing. Aristotle (1962) The Politics, translated by T. A. Sinclair. Middlesex: Penguin Books. 
Aristotle (1976) The Nicomachean Ethics, translated by J.A.K. Thomson. London: Penguin Books.

Beiner, R. (1983) Political Judgement. London: Methuen.

Bender, J. and Wellbery, D. E. (1990) Rhetoricality: On the Modernist Turn of Rhetoric. In: J. Bender and D. E. Wellbery (eds.) The Ends of Rhetoric: History, Theory, Practice. Stanford: Stanford University Press.

Benhabib, S. (1996) Towards a Deliberative Model of Democratic Legitimacy. In: S. Benhabib (ed.) Democracy and Difference: Contesting the Bounds of the Political. Princeton: Princeton University Press.

Blaug, R. (1996) New Theories of Discursive Democracy: A User's Guide. Philosophy and Social Criticism 22(1): 49-80.

Bohman, J. (1996) Public Deliberation, Pluralism, Complexity, and Democracy. Cambridge, MA: MIT Press.

Bohman, J. (1997) Deliberative Democracy and Effective Social Freedom: Capabilities, Resources, and Opportunities. In: J. Bohman and W. Rehg (eds.) Deliberative Democracy: Essays on Reason and Politics. Cambridge. MA: MIT Press.

Bohman, J. (2012) Representation in the Deliberative System. In: J. Parkinson and J. Mansbridge (eds.) Deliberative Systems. Cambridge: Cambridge University Press.

Booth, R. (2014) US investors set to sell New Era estate in London after protests. The Guardian, 18 December, https://www.theguardian.com/society/2014/dec/18/us-investorsset-sell-new-era-estate-london-protests-westbrook

Brunschwig, J. (1996) Aristotle's Rhetoric as a "Counterpart" to Dialectic. In: A. O. Rorty (ed.) Essay on Aristotle's Rhetoric. Berkeley: University of California Press.

Cadwalladr, C. (2017) Robert Mercer: the big data billionaire waging war on mainstream media. The Guardian, $26 \quad$ February, https://www.theguardian.com/politics/2017/feb/26/robert-mercer-breitbart-war-on-mediasteve-bannon-donald-trump-nigel-farage

Chambers, S. (2009) Rhetoric and the Public Sphere: Has Deliberative Democracy Abandoned Mass Democracy? Political Theory 37(3): 323-50.

Charland, M. (1987) Constitutive Rhetoric: The Case of the Peuple Québécois. The Quarterly Journal of Speech 73(2): 133-150.

Cohen, J. (1997) Deliberation and Democratic Legitimacy. In: J. Bohman and W. Rehg (eds.) Deliberative Democracy: Essays on Reason and Politics. Cambridge. MA: MIT Press.

Cooper J. M. (1994) Ethical-Political Theory in Aristotle's Rhetoric. In: D. J. Furley and A. Nehmas (eds.) Aristotle's 'Rhetoric': Philosophical Essays. Princeton: Princeton University Press.

Devereux \& Onians. (2010) Interview with Stewart Lee. Devereux \& Onians Productions. 15 January, http://www.atkinsoft.com/stewartlee.html.

Dow, J. (2015) Passions and Persuasion in Aristotle's Rhetoric. Oxford: Oxford University Press.

Dryzek, J. (2000) Deliberative Democracy and Beyond: Liberals, Critics, Contestations. Oxford: Oxford University Press.

Dryzek, J. (2010) Rhetoric in Democracy: A Systematic Appreciation. Political Theory 38(3): 319-339.

Endberg-Pederesen, T. (1996) Is There an Ethical Dimension to Aristotelian Rhetoric? In: A. O. Rorty (ed.) Essay on Aristotle's Rhetoric. Berkeley: University of California Press.

Farrell, T. B. (1993) The Norms of Rhetorical Culture. New Haven: Yale University Press. 
Fontana, B. (2005) Rhetoric and the Roots of Democratic Politics. In: B. Fontana, C. J. Nederman and G. Remer (eds.) Talking Democracy: Historical Perspectives on Rhetoric and Democracy. Pennsylvania: The Pennsylvania State University Press.

Fox 10. (2017) 'New White House Communications Director Anthony Scaramucci Speaks After Sean Spicer Resigns'. 21 July, https://www.youtube.com/watch?v=fz-VaIjXorQ.

Frank, J. (2009) Staging the Dissensus: Frederick Douglass and 'We, the People'. In: A Schaap (ed.) Law and Agonistic Politics. London: Ashgate.

Fung, A. (2005) Deliberation before the Revolution: Towards an Ethics of Deliberative Democracy in an Unjust World. Political Theory 33(3): 397- 419.

Garsten, B. (2006) Saving Persuasion: A Defence of Rhetoric and Judgement. Cambridge, MA: Harvard University Press.

Garver, E. (1994) Aristotle's Rhetoric: An Art of Character. Chicago: University of Chicago Press.

Gorgias (1991) Encomium of Helen. In: G. A. Kennedy, On Rhetoric: A Theory of Civic Discourse, translated by George A. Kennedy. Oxford: Oxford University Press.

Guttmann, A. and Thompson, D. (1996) Democracy and Disagreement. Harvard: Harvard University Press.

Guttmann, A. and Thomson, D. (2004) Why Deliberative Democracy? Princeton: Princeton University Press 2004.

Habermas, J. (1997) Between Facts and Norms: Contributions to Discourse Theory of Law and Democracy, translated by W. Rehg. Cambridge: Polity Press, 1997.

Haliwell, S. (1996) The Challenge of Rhetoric to Political and Ethical Theory in Aristotle. In: A. O. Rorty (ed.) Essay on Aristotle's Rhetoric. Berkeley: University of California Press.

Hauser, G. A. (1995) Between Philosophy and Rhetoric: Interpositions within Traditions. Philosophy and Rhetoric 28(3): iii-xvii.

Irwin, T. H. (1996) Ethics in the Rhetoric and in the Ethics. In: A. O. Rorty (ed.) Essay on Aristotle's Rhetoric. Berkeley: University of California Press.

Kant, I. (1953) The Critique of Judgement, translated by J. C. Meredith. Oxford: Oxford University Press.

Knight, J. and Johnson, J. (1997) What Sort of Equality Does Deliberative Democracy Require? In J. Bohman and W. Rehg (eds.) Deliberative Democracy: Essays on Reason and Politics. Cambridge. MA: MIT Press.

Krause, S. H. (2008) Civil Passions: Moral Sentiment and Democratic Deliberation. Princeton: Princeton University Press.

Manin, B. (1987) On Legitimacy and Political Deliberation. Political Theory 15(3): 338-368.

Mansbridge, J., Bohman, J., Chambers, C., Christano, T., Fung, A., Parkinson, J., Thompson, D. F., Warren, M. E. (2012) A Systemic approach to deliberative democracy. In Deliberative Systems (eds.) J. Parkinson and J. Mansbridge. Cambridge: Cambridge University Press.

McCabe, M. M. (1994) Aristotle's Defence of Rhetoric. In: D. J. Furley and A. Nehmas (eds.) Aristotle's 'Rhetoric': Philosophical Essays. Princeton: Princeton University Press.

Meyer, M. (1994) Rhetoric, Language, and Reason. Pennsylvania: Pennsylvania University Press.

Norval, A. J. (2007) Aversive Democracy: Inheritance and Originality in the Democratic Tradition. Cambridge: Cambridge University Press.

Nussbaum, M. C. (1996) Aristotle on Emotion and Rational Persuasion. In: A. O. Rorty (ed.), Essays on Aristotle's Rhetoric. Berkeley: University of California Press.

Nussbaum, M. C. (1990) Love's Knowledge: Essays on Philosophy and Literature. Oxford: Oxford University Press. 
Owen, D, and Smith, S. (2015) Survey Article: Deliberation, Democracy, and the Systemic Turn. The Journal of Political Philosophy 23 (2): 213-234

Perelman, C. (1982) The Realm of Rhetoric, translated by W. Kluback. Indiana: University of Notre Dame Press.

Remer, G. (1999) Two Models of Deliberation: Oratory and Conversation in Ratifying the Constitution. The Journal of Political Philosophy 8(1): 68-90.

Ricoeur, P. (2003) The Rule of Metaphor: The Creation of Meaning in Language, translated by R. Czerny, K. McLaughlin and J. Costello. London: Routledge.

Rostbøll, C. F. (2008) Deliberative Freedom: Deliberative Democracy as Critical Theory. Albany: Suny Press.

Sachs, J. (2009) Introduction. In: Sachs, J. Plato Gorgias and Aristotle Rhetoric Newburyport, MA: Focus Publishing.

Sanders, L. (1997) Against Deliberation. Political Theory 25(3): 347-376.

Schiappa, E. (2001) Second Thoughts on the Critique of Big Rhetoric. Philosophy and Rhetoric 34(3): 260-274.

Schütrumpf, E. (2015) Some Observations on the Introduction to Aristotle's Rhetoric. In: Furley, D. J. and Nehmas, A. (eds.) Aristotle's "Rhetoric": Philosophical Essays. Princeton: Princeton University Press.

Sprute, J. (1994) Aristotle and the Legitimacy of Rhetoric. In: Furley, D. J. and Nehmas, A. (eds.) Aristotle's "Rhetoric": Philosophical Essays. Princeton: Princeton University Press.

Tully, J. (2002) The Unfreedom of the Moderns in Comparison to Their Ideals of Constitutional Democracy. The Modern Law Review 65 (2): 204-228

Tyler, I. (2013) Revolting Subjects: Social Abjection and Resistance in Neoliberal Britain. London: Zed Books.

Wardy, R. (1996) Mighty Is the Truth and It Shall Prevail In: A. O. Rorty (ed.) Essay on Aristotle's Rhetoric. Berkeley: University of California Press.

Welsh, S. (2002) Deliberative Democracy and the Rhetorical Production of Political Culture. Rhetoric and Public Affairs 5(4): 679-707.

Welsh, S. (2013) The Rhetorical Surface of Democracy. Plymouth: Lexington Books.

Wintour, P. and Collier, H. (2014) Nigel Farage launches Ukip campaign amid criticism of 'racist' rhetoric. The Guardian, 22 April, http://www.theguardian.com/politics/2014/apr/22/nigel-farage-ukip-european-electionscampaign

Yack, B. (2003) Rhetoric and Public Reasoning: An Aristotelian Understanding of Public Deliberation. Political Theory 34(4): 417-438.

Young, I. M. (1996) Communication and the Other: Beyond Deliberative Democracy. In S. Benhabib (ed.) Democracy and Difference: Contesting the Bounds of the Political. Princeton: Princeton University Press.

Young, I. M. (2000) Inclusion and Democracy. Oxford: Oxford University Press.

Young, I. M. (2001) Activist Challenges to Deliberative Democracy. Political Theory 29(5): 670-690. 